\title{
Peran Komisi Pemilihan Umum untuk Meningkatkan Peran Perempuan dalam Partisipasi Politik Tahun 2019
}

\author{
Amelia Haryanti ${ }^{a, 1 *}$ \\ aProgram Studi Pendidikan Pancasila dan Kewarganegaraan, \\ Fakultas Keguruan dan Ilmu Pendidikan, Universitas Pamulang, Tangerang Selatan \\ 1dosen00811@unpam,ac.id \\ *korespondensi penulis
}

Naskah diterima: 05-02-19, direvisi: 10-03-19, disetujui: 30-03-19

DOI: http://dx.doi.org/10.32493/jpkn.v6i1.y2019.p37-50

\begin{abstract}
Abstrak
Tujuan dari penelitian ini adalah memberikan pemahaman dan gambaran mengenai hambatan dan strategi Komisi Pemilihan Umum dalam meningkatkan partisipasi politik perempuan. Metode yang digunakan dalam penelitian ini adalah metode kualitatif dan teknik pengumpulan data digunakan melalui wawancara dan dokumentasi. Hasil penelitian mengungkapkan bahwa rendahnya peran perempuan dalam partisipasi politik adalah karena berbagai macam hambatan yang harus di atasi oleh komisi pemilihan umum agar terjadi peningkatan dalam partisipasi politik yang akan datang. Hasil penelitian menunjukan bahwa upaya untuk mencapai target tersebut, KPU Kota Tangerang Selatan menerapkan sosialisasi politik dengan menerapkan strategi ofensif dan defensif kepada pemilih perempuan secara bersamaan dengan kelompok sasaran yang berbeda dari pemilih perempuan untuk meningkatkan peran perempuan dalam partisipasi politik di Kota Tangerang Selatan pada pemilihan umum mendatang.
\end{abstract}

Kata-kata kunci: strategi politik; sosialisasi politik; pemilih perempuan

\begin{tabular}{l} 
Abstract \\
\hline The purpose of this study is to provide an understanding and overview of the obstacles and \\
strategies of the General Election Commission in increasing women's political participation. The \\
method used in this study is a qualitative method and data collection techniques used through \\
interviews and documentation. The results of the study revealed that the low role of women in \\
political participation was due to various kinds of obstacles that had to be overcome by the \\
election commission so that there would be an increase in political participation to come. The \\
results showed that in an effort to achieve these targets, the South Tangerang KPU implemented \\
political outreach by implementing offensive and defensive strategies to female voters \\
simultaneously with different target groups of women voters to increase the role of women in \\
political participation in South Tangerang City in general elections. future.
\end{tabular}

Keywords: political strategy; political socialization; female voter 


\section{Pendahuluan}

Pelaksanaan pemilihan presiden dan wakil presiden serta pemilihan anggota legislatif di Indonesia dilaksanakan melalui mekanisme pemilihan umum yang dilaksanakan setiap lima tahun sekali. Terakhir pelaksanaan pemilihan umum di Indonesia dilaksanakan pada tanggal 17 April 2019 telah berhasil dilaksankan dengan demokratis. KPU kota Tangerang Selatan sebagai perwakilan KPU pusat ikut serta mendukung pelaksanaan pemilihan umum serentak dalam pemilihan anggota legislatif dan eksekutif, sesuai dengan amanat Undang-Undang Nomor 15 Tahun 2011 tentang Penyelenggaraan Pemilu yang diberikan tugas dan wewenang untuk menyelenggarakan seluruh tahapan pemilihan umum. Salah satu tugas dari KPU Tangerang Selatan adalah melaksanakan sosialisasi politik.

Berdasarkan data KPU Kota Tangerang Selatan, daftar pemilih yang tercatat sebagai daftar pemilih tetap adalah 839.464 orang, dari jumlah tersebut, jumlah pemilih laki-laki sebanyak 416.048 orang, dan sisanya sebanyak 423.416 orang adalah pemilih perempuan. Dari data diatas, membuktikan bahwa pemilih perempuan di kota Tangerang Selatan lebih banyak dari pada pemilih laki-laki prosentase yang cukup signifikan yakni sebesar 50,43\%. (Data KPU 2015)

Berdasarkan data rekapitulasi perolehan suara pemilu 2019 untuk kota Tangerang Selatan menunjukan peningkatan partisipasi perempuan dalam menggunakan hak pilihnya dibandingkan pemilu sebelumnya. Namun dari jumlah ini, belum dapat dikatakan mewakili partisipasi perempuan tingkat nasional seperti yang sudah ditetapkan oleh KPU sebesar $75 \%$ yang dituangkan dalam rencana strategis KPU. Rumusan masalah dalam penelitian ini adalah 1). Faktor apa saja yang menjadi hambatan pemilih perempuan dalam partisipasi politik di kota Tangerang Selatan, 2). Strategi apa yang dilakukan oleh KPU Kota Tangerang Selatan dalam melalukan kegiatan sosialisasi politik kepada pemilih perempuan?. Penelitian tentang meningkatkan partisipasi politik perempuan oleh penyelenggara pemilu dalam pelaksanaan sosialisasi politik untuk meningkatkan partisipasi politik masih jarang dilakukan, sebagian besar penelitian terdahulu membahas strategi politik yang digunakan untuk tujuan pemenangan pemilu oleh kandidat, tim pemenangan, atau oleh partai politik.

Dalam penelitian ini, peneliti hanya membatasi pada peran dan strategi dari Komisi Pemilihan umum dalam upaya meningkatkan partisipasi politik bagi perempuan yang sudah mempunyai hak pilih. Adapun tujuan dari penelitian ini adalah sebagai bahan informasi bagi masyarakat, praktisi khususnya praktisi dalam mengambil kebijakan berkenaan dengan upaya meningkatkan partisipasi politik di masyarakat.

\section{Metode}

Penelitian ini menggunakan metode kualitatif, dipilih karena lebih menekannkan pada kedalaman data dan penjelasan, dengan teknik pengumpulan 
data yang dilakukan melalui wawancara dan dokumentasi. (Sarwono, Jhonathan, 2006) Sumber data berasal dari data primer melalui wawancara dan data sekunder berupa literatur-literatur dan dokumen-dokumen yang berkaitan dengan kegiatan sosialisasi politik. Dalam penelitian ini, pengjian keabsahan data didasarkan pada deraajat kebenaran dan kepercayaan data yang diperoleh, dan kesesuaian terhadap peraturan perundang-undangan beserta dokumen resmi yang dikeluarkan oleh instansi yang berwenang.

\section{Hasil dan Pembahasan}

Hambatan pemilih perempuan dalam partisipasi politik di Kota Tangerang Selatan

Jika dilihat dari letak dan kondisi geografisnya, Kota Tangerang Selatan tidak memiliki hambatan bagi pemilih untuk hadir dalam menyuarakan hak suaranya ke tempat pemungutan suara (TPS) karena luasnya hanya sekitar 147,9 $\mathrm{Km}^{2}$, yang terdiri dari dari 7 (tujuh) kecamatan, 49 (empat puluh sembilan) kelurahan dan 5 (lima) desa, sehingga jarak tempuh menuju TPS untuk menggunakan hak pilihnya relatif dekat. Kemudian secara topografis akses jalan di Kota Tangerang Selatan juga relatif mudah untuk dilakui pemilih untuk menuju TPS karena wilayahnya relatif datar dengan kemiringan tanah rata-rata $0-3 \%$ dengan ketinggian wilayah antara 0-25 mdpl, sehingga termasuk daerah yang cukup rata dan bebas banjir. Adanya fenomena jumlah permpuan yang sudah memiliki hak pilih lebih banyak dibanding pemilih laki-laki di kota Tangerang Selatan, namun tingkat partisipasi pemilih perempuan pada pemilu 2019 tetap tidak bisa mencapai target.

Partisipasi perempuan di Kota Tangerang Selatan dalam menyuarakan suaranya dalam pemilihan umum menjadi sasaran dalam sosialisasi politik oleh KPU kota Tangerang Selatan. Pemilih perempuan dijadikan sasaran karena menurut data pemilih tetap, (Hafidz Liza, 2004), jumlahnya lebih banyak dibandingkan pemilih laki-laki, selain itu, dilihat dari tingkat pendidikan, pemilih perempuan di Kota Tangerang Selatan lebih banyak memiliki hambatan, dengan kata lain rendahnya mayoritas pendidikan perempuan yang sudah mempunyai hak pilih di Kota Tangerang Selatan menjadi salah satu hambatan dalam mengakses informasi berkaitan dengan cara mengikuti pemilihan umum.

Hambatan pertama dalam bidang pendidikan yaitu, masih banyaknya perempuan di Kota Tangerang Selatan yang buta huruf. Perempuan berusia 10 tahun keatas yang buta huruf jumlahnya lebih banyak dibandingkan dengan lakilaki yaitu mencapai 3,22\% dari jumlah penduduk, sedangkan laki-laki hanya sebanyak 1,57\%. (Badan Statistik Tangerang Selatan). Hal tersebut disebabkan karena penduduk perempuan di Kota Tangerang Selatan yang berusia 10 tahun keatas tidak bersekolah jumlahnya mencapai $1,07 \%$, sedangkan laki-laki yang tidak bersekolah hanya $0,70 \%$ dari jumlah penduduk.

Rendahnya tingkat pendidikan, kemampuan membaca dan menulis 
mengakibatkan rendahnya pula pengetahuan serta pemahaman yang dimiliki sehingga pada akhirnya dapat menimbulkan rendahnya kesadaran sipil dan politik bagi perempuan di Kota Tangerang Selatan. Hambatan kedua berasal dari bidang ekonomi terkait dengan angkatan kerja atau kesempatan kerja. Jumlah perempuan di Kota Tangerang Selatan yang bekerja, baik pada sektor jasa, pertanian, industri, konstruksi, perdagangan, transportasi, keuangan dan lainnya hanya sejumlah 24,6\% dari seluruh angkatan kerja sebesar 64.382 jiwa pada tahun 2018 .Artinya banyak perempuan di Kota Tangerang Selatan yang tidak bekerja atau hanya mengurus rumah tangga, jadi kecenderungan perempuan berperan hanya menjadi ibu rumah tangga saja sehngga hanya sedikit sekali perempuan yang bekerja di sektor publik. (Hatima Tati, 2000) Kemudian hambatan ketiga yang berasal dari faktor sosial, dimana banyak pemilih perempuan di Kota Tangerang Selatan yang tinggal di lingkungan asrama TNI/Polri. Perempuan yang tinggal di lingkungan asrama tersebut pada umumnya memiliki kepala keluarga sebagai anggota TNI/Polri yang tidak memiliki hak politik. Jadi perempuan yang tinggal di lingkungan tersebut jarang mendapatkan informasi seputar politik, sehingga kurang tertarik dengan urusan politik. Perempuan di lingkungan asrama lebih banyak beraktifitas terkait urusan kedinasan dari suaminya. Selain hambatan dalam hal pendidikan, ekonomi, dan sosial sebagaimana diuraikan di atas, menurut
Nining Mardiyani juga terdapat hambatan di bidang politik yang dialami oleh kaum perempuan, yaitu kurangnya sosialisasi politik yang khusus menyasar kaum perempuan dengan mengangkat isu-isu tentang perempuan yang dilakukan oleh partai politik ataupun penyelenggara Pemilu. (Buya Hamka, 2017). Mengatasi berbagai hambatan yang dialami oleh pemilih perempuan di Kota Tangerang Selatan dalam mengakses dan mendapatkan informasi tentang Pemilu dan tahapan Pemilu Kota Tangerang Selatan, merupakan tantangan bagi KPU Kota Tangerang Selatan dalam menjalankan agenda sosialisasi politik pada Pemilu Kota Tangerang Selatan tahun 2019. Dibutuhkan pendekatan yang sesuai dengan karakteristik pemilih perempuan. (Mariyah, 2001:15) Untuk itu sosialisasi politik yang dilakukan oleh KPU Kota Tangerang Selatan kepada pemilih perempuan penting dilakukan, melalui kegiatan-kegiatan yang familier terhadap perempuan agar hambatanhambatan bagi pemilih perempuan dalam memperoleh informasi kepemiluan dan tahapan Pemilu Kota Tangerang Selatan tahun 2019 dapat teratasi.

\section{Strategi Komisi Pemilihan Umum} untuk Meningkatkan Sosialisasi Politk Perempuan dalam Pemilu di Kota tangerang Selatan

Sosialisasi politik harus dilakukan oleh KPU Kota Tangerang Selatan sebagai cara yang tepat digunakan untuk meningkatkan partisipasi perempuan dalam rangka mensukseskan pemilihan umum tahun 2019. Strategi sosialisasi 
politikini juga digunakan untuk proses pemilihan kepala daerah.(Pusat Kajian Gender dan Wanita). Dalam melaksanakan sosialisasi politik ini, strategi sosialisasi politik dalam Pilkada digunakan untuk merealisasikan cita-cita politik agar pengetahuan masyarakat meningkat dalam memahami dan menyadari hak dan kewajibannya nya sebagai warganegara dalam menyuarakan aspirasinya. Sebagai badan yang berwenang menyelenggarakan pemilihan umum, berbagai upaya dan usaha dilakukan oleh KPU Kota Tangerang Selatan agar partisipasi politik masyarakat terutama partisipasi pemilih perempuan di Kota Tangerang Selatan lebih meningkat dari masa sebelumnya.

Penggunaan strategi yang tepat pada akhirnya akan mengerucut pada kegiatankegiatan yang lebih kongkrit, spesifik dan dapat diimplementasikan di lapangan. Tujuan utama dari strategi itu pada prinsipnya adalah pencapaian target. Pada penyelenggaraan Pemilu Tahun 2019 secara serentak, target yang ditetapkan oleh KPU untuk partisipasi ini yakni sebesar $77,5 \%$ bagi seluruh Indonesia sebagaimana tercantum dalam Rencana Strategis KPU Tahun 2015-2019. Keberhasilan terhadap pencapaian tujuan tersebut sangat ditentukan oleh kinerja KPU Kota Tangerang Selatan sebagai badan penyelenggara Pemilu dalam mensinergikan berbagai potensi yang dimiliki oleh Kota Tangerang Selatan baik itu menyangkut potensi sumber daya manusia, dana dan dukungan pemangku kepentingan dalam Pemilu. (Nur Hidayat, 211:225) Keterpaduan dan keselarasan dalam mengelola semua elemen tersebut yang tertuang dalam strategi sosialisasi politik KPU Kota Tangerang Selatan yang kemudian diimplementasikan dalam berbagai kegiatan, agar masyarakat lebih memahami dan menyadari dalam menggunakan hak pilihnya sehingga partisipasi politik masyarakat Tangerang Selatan menjadi lebih meningkat dalam pemilihan umum Tahun 2019.

Pada penyelenggaraan pemilu sebelumnya KPU Kota Tangerang Selatan dalam melakukan sosialisasi politik belum terfokus kepada kelompok pemilih perempuan meskipun jumlahnya melebihi setengah dari seluruh jumlah pemilih. Kemudian pada pemilu tahun 2019 KPU Kota Tangerang Selatan menetapkan partisipasi dan peran perempuan sebagai salah satu salah satu sasaran yang cukup strategis dalam agenda sosialisasi politik. Banyaknya pemilih perempuan dapat menjadi peluang bagi KPU Kota Tangerang Selatan untuk meningkatkan prosentase partisipasi pemilih pada Pemilu tahun 2019 dengan cara melakukan sosialisai politik terfokus pada segmen pemilih perempuan, dengan harapan bahwa pemilih perempuan dengan jumlah yang banyak akan mendorong peningkatan prosentase partisipasi pemilih secara signifikan. Namun, dengan banyaknya jumlah pemilih perempuan juga dapat menjadi ancaman, yaitu berupa penurunan prosentase partisipasi pemilih pada pemilu tahun 2019 apabila pemilih perempuan tersebut banyak yang tidak menggunakan hak pilihnya dalam Pemilu. Upaya antisipasi KPU Kota Tangerang 
Selatan yakni menerapkan sosialisasi politik sebagai upaya untuk meningkatkan partisipasi perempuan yang sudah mempnyai hak pilih melalui strategi sosialisasi politik sebagai upaya agar partisipasi pemilih perempuan menjadi meningkat pada pemilu tahun 2019. Dalam melaksanakan kegiatan sosialisasi politik kepada pemilih perempuan, KPU Kota Tangerang Selatan menerapkan dua jenis strategi politik, yaitu strategi ofensif (menyerang) dan strategi defensif (bertahan) sebagaimana menurut Scroder:

\section{Strategi Ofensif}

Strategi ofensif yang digunakan oleh KPU Kota Tangerang Selatan dalam sosialisasi politik dimaksudkan untuk meningkatkan jumlah pemilih perempuan dalam menggunakan hak pilihnya pada Pemilu tahun 2019. Melalui kegiatankegiatan yang familier sesuai dengan karakteristik dan aktifitas kelompok target pemilih perempuan, diharapkan materi sosialisasi politik dapat diterima dengan baik, sehingga memahami dan mengetahui tahapan-tahapan mengenai pemilu sehingga keberhasilan pemilu tahun 2019 dapat meningkat dari periode sebelumnya.

Kegiatan tersebut terdiri dari:1) Kerjasama dengan Organisasi Perempuan. Salah upaya dilakukan oleh KPU Kota Tangerang Selatan dalam mensosialisasikan Pemilu dan tahapan pemilu tahun 2019 kepada pemilih perempuan melalui pendekatan formal difokuskan pada kegiatan yang berkaitan dengan aktifitas organisasi-organisasi perempuan yang terdapat di Kota
Tangerang Selatan. Untuk menyampaikan informasi kepemiluan dan tahapan pemilu Kota Tangerang Selatan tahun 2019 secara lebih tepat dan akurat sebagaimana menurut Scroder dilakukan dengan menggolongkan organisasi-organisasi perempuan tersebut secara lebih spesifik berdasarkan profesi dan agama sebagai berikut: (P.Scroder, 2010:328), Pertama, organisasi kekaryaan bidang perempuan, KPU Kota Tangerang Selatan melakukan sosialisasi Pemilu dan tahapan pemilu tahun 2019 kepada organisasi kekaryaan bidang perempuan yang terdaftar di Kota Tangerang selatan dimaksudkan untuk memberikan pengetahuan tentang kepemilu dan tahapan pemilu kepada istri anggota TNI/Polri karena mereka mempunyai kepala keluarga yang secara profesionalisme tidak pernah bersentuhan dengan aktifitas politik. Upaya yang dilakukan oleh KPU Kota Tangerang Selatan dengan menggandeng organisasi kekaryaan bidang perempuan tersebut merupakan salah satu strategi untuk memperluas kelompok target, melalui kegiatan sosialisasi tentang kepemiluan dan tahapan pemilu tahun 2019 yang sebelumnya belum pernah dilakukan. Organisasi kekaryaan berdasarkan profesi baik yang dibentuk secara formal ataupun informal merupakan saluran penyampaian informasi yang paling jelas, dimana setiap anggota akan mengidentifikasikan diri dalam suatu organisasi tersebut dan menjadikan aktifitas-aktifitas organisasi, termasuk kegiatan sosialisasi kepemiluan dan tahapan pemilu tahun 2019 sebagai acuan (reference) dalam kehidupan politik sebagaimana menurut Mas`oed \& 
MacAndrews. (Mas'oed dan Mac Anrdrew, 2011:48), Kedua , organisasi keagamaan bidang perempuan, KPU Kota Tangerang Selatan melakukan kerjasama dengan pengurus organisasi keagamaan bidang perempuan dalam melaksanakan agenda sosialisasi kepemiluan dan pemilu tahun 2019. Kerjasama dilakukan dengan melibatkan pengurus organisasi tersebut untuk melaksanakan sosialisasi kepada anggotanya. Pengurus yang ditunjuk mewakili organisasinya kemudian diberikan pembekalan materi kepemiluan dan tahapan pemilu tahun 2019 oleh KPU Kota Tangerang Selatan. Selain itu KPU Kota Tangerang Selatan juga memberikan bahan sosialisasi berupa brosur, leaflet, poster, dan sticker sebagai media untuk menyampaikan informasi kepemiluan dan tahapan pemilu tahun 2019 kepada anggotanya. Organisasi keagamaan bidang perempuan di Kota Tangerang Selatan terdiri dari Fatayat NU, Nasyiatul Aisiyah, PD. Aisiyah, PC. Muslimat NU, dan Gabungan Wanita Gereja Kota Tangerang Selatan. Pengurus organisasi keagamaan bidang perempuan yang telah mengikuti kegiatan pembekalan berupa materi kepemiluan dan tahapan pemilu tahun 2019 kemudian melakukan sosialisasi kepada anggotanya. Pengurus organisasi tersebut diberikan keleluasaan dalam menjalankan agenda sosialisasi yang disesuaikan dengan kebiasaan yang berlaku dalam kegiatan rutinnya, seperti mengatur jadwal sosialisasi, tempat sosialisasi dan metode penyampaian informasi yang akan digunakan. Hal ini dilaksanakan agar para anggota organisasi keagamaan bidang perempuan merasa familier atau terbiasa dengan aktifitas yang selama ini sudah dijalankan dalam penyampaian informasi.(Rush. M dan P. Althoff, 2013:27)

Dalam organisasi keagamaan bidang perempuan setiap anggota mempunyai ikatan berupa keyakinan yang sama dan sering berinteraksi secara rutin dan bersama-sama, sehingga akan mendorong masyarakat dalam penyesuaian diri dalam bersikap atau bertingkah laku sesuai yang dianut oleh organisasi tersebut. Jadi dengan adanya sosialisasi kepemiluan dan tahapan pemilu tahun 2019 kepada organisasi keagamaan bidang perempuan juga akan mendorong para anggota untuk menyesuaikan diri terhadap nilai-nilai yang disampaikan dalam sosialisasi tersebut. 2) Bibentuknya relawan perempuan sebagai bentuk pelaksanaan demokrasi. Selain melalui pendekatan formal, upaya pendekatan kepada pemilih perempuan juga dilakukan secara informal melalui sosialisasi politik kepada pemilih perempuan yang tidak menjadi anggota organisasi perempuan, hal tersebut dilakukan dengan strategi membentuk relawan demokrasi segmen perempuan. Relawan demokrasi merupakan gerakan sosial yang dimaksudkan untuk meningkatkan partisipasi dan kualitas pemilih dalam menggunakan hak pilih dalam Pemilu. Relawan demokrasi melibatkan peranserta masyarakat yang seluas-luasnya dimana mereka ditempatkan sebagai pelopor demokrasi bagi komunitas atau lingkungannya. (Bina Partisipasi Masyarakat, KPU,2015:28) Relawan demokrasi segmen perempuan menjadi mitra KPU Kota Tangerang 
Selatan dalam melaksanakan agenda sosialisasi politik yang diharapkan mampu menumbuhkan kesadaran terhadap pentingnya Pemilu termasuk Pilkada dalam kehidupan berbangsa dan bernegara. Relawan demokrasi segmen perempuan selain melakukan sosialisasi politik dengan mendatangi rumah-rumah yang menjadi target sesuai dengan wilayah kerjanya, juga melakukan kegiatan sosialisasi politik secara bersamasama di keramaian seperti kepada para pedagang pasar tradisional yang ada di Kota Tangerang Selatan, yang terdiri dari pasar Cimanggis, pasar Ciputat, pasar Reni Jaya, dan pasar Serpong. Pedagang pasar dipilih sebagai kelompok target dengan pendekatan informal karena sebagian besar pedagang tradisional adalah perempuan dan mereka menghabiskan lebih banyak waktu untuk berjualan di pasar. Kehadiran relawan demokrasi segmen perempuan juga memberikan warna baru dalam kegiatan sosialisasi politik sebagai salah satu strategi yang diterapkan oleh KPU Kota Tangerang Selatan dalam pemilu tahun 2019. 3) Pemanfaatan Media Massa Lokal Strategi untuk mengakses kelompok target juga dilakukan melalui pendekatan media, agar KPU Kota Tangerang Selatan dalam menyampaikan informasi kepemiluan dan tahapan pemilu tahun 2019 dapat lebih luas menjangkau pemilih perempuan di Kota Tangerang Selatan secara massif tanpa terkecuali. KPU Kota Tangerang Selatan membangun hubungan dengan media cetak lokal dan media elektronik lokal yang ada di Kota Tangerang Selatan melalui kegiatan sebagai berikut: Pertama,
Rubrik Tanya Jawab "Masyarakat Bertanya Pemilu, KPU Menjawab” di Surat Kabar Harian Lokal. Rubrik tanya jawab di surat kabar harian lokal (SKHL) Radar Tangerang Selatan merupakan tindak lanjut dari kegiatan "media visit" yang dilakukan oleh KPU Kota Tangerang Selatan. SKHL Radar Tangerang Selatan dipilih sebagai media cetak untuk memuat rubrik tanya jawab tentang kepemiluan dan tahapan pemilu tahun 2019 karena merupakan SKHL tertua dan mempunyai kapasitas edar paling tinggi di Kota Tangerang Selatan. Berdasarkan company profile SKHL Magelang Ekspres merupakan SKHL pertama di Kota Tangerang Selatan yang berdiri sejak tahun 2010, mulai tahun 2013 mempunyai kapasitas cetak sebanyak 18.000 eksemplar dengan wilayah edar di wilayah Tangerang Selatan sebanyak 45,3\%,. Rubrik tanya jawab KPU Kota Tangerang Selatan diampu oleh KPU Kota Tangerang Selatan yang menjawab pertanyaan dari masyarakat seputar kepemiluan dan tahapan pemilu Tahun 2019, pertanyaan tersebut dikirimkan ke redaksi SKHL Radar Tangerang Selatan. Rubrik tanya jawab KPU Kota Tangerang Selatan dengan masyarakat tersebut diberi judul "Masyarakat Bertanya Pemilu, KPU Menjawab", yang dimuat satu kali dalam seminggu, yaitu pada hari sabtu selama tahapan pemilu tahun 2019 berjalan. Rubrik tanya jawab "Masyarakat Bertanya Pemilu, KPU Menjawab” memang tidak secara spesifik membahas isu-isu yang berkaitan dengan pemilih perempuan, namun animo perempuan di Kota Tangerang Selatan untuk mengirimkan 
pertanyaan seputar kepemiluan dan tahapan pemilu tahun 2019 ke redaksi Radar Tangerang Selatan cukup tinggi. Kedua, Dialog Interaktif "Perempuan Cerdas Berdemokrasi" di Lembaga Penyiaran Publik Lokal. Selain melalui media cetak lokal, KPU Kota Tangerang Selatan juga melakukan kerjasama dengan lembaga penyiaran publik lokal (LPPL) Kerjasama dituangkan dengan perjanjian kerja sama antara KPU Kota Tangerang Selatan dengan Dinas Perhubungan, Sosialisasi Pemilu dan Penyelenggaraan Pemilu Kota Tangerang Selatan Tahun 2019. Isi perjanjian tersebut berupa pelaksanaan sosialisasi oleh KPU Kota Tangerang Selatan melalui kegiatan dialog interaktif yang difasilitasi oleh Dialog interaktif dilaksanakan 1 kali dalam seminggu setiap hari rabu pukul 16.30 sampai dengan 17.30 WIB selama tahapan pemilihan umum tahun 2019 berlangsung. Adapun kelompok target sosialisasi politik dalam dialog interaktif tersebut terbagi menjadi dua segmen, yaitu untuk segmen pemilih secara umum dilaksanakan pada hari rabu minggu pertama dan ketiga dengan tema "Pemilu Bermartabat”, sedangkan untuk segmen pemilih perempuan pada hari rabu minggu kedua dan keempat dengan tema "Perempuan Cerdas Berdemokrasi". Pengisi acara dalam dialog interaktif tersebut adalah 5 orang anggota KPU Kota Tangerang secara bergantian setiap minggunya, dengan dipandu oleh pembawa acara dari lokal. Keaktifan pemilih perempuan dalam dialog interaktif melalui radio dengan materi kepemiluan dan tahapan pemilu tahun
2015 menunjukkan bahwa adanya peningkatan kesadaran pemilih perempuan untuk ikut serta dalam aktifitas yang berkaitan dengan penanaman nilai-nilai politik. Kemudian kesadaran tersebut terus dibangun dan ditingkatkan oleh KPU Kota Tangerang Selatan dengan menayangkan berbagai iklan layanan masyarakat (ILM) di tempat-tempat strategis yang sering dilalui oleh masyarakat, juga dibuat dalam bentuk visual yang dimuat di surat kabar harian lokal yang ada di Kota Tangerang Selatan. ILM tersebut berisi ajakan kepada pemilih untuk aktif dalam memastikan bahwa namanya sudah terdaftar sebagai pemilih di PPS, ajakan untuk mencermati visi dan misi pasangan calon presiden dan anggota legislatif, ajakan untuk ikut serta mendaftar sebagai penyelenggara Pemilu, dan ajakan untuk hadir dan menggunakan hak pilihnya di TPS pada hari pemungutan suara tanggal 17 April 2019.

\section{Strategi Defensif}

KPU Kota Tangerang Selatan selain menggunakan strategi ofensif dengan tujuan untuk meningkatkan jumlah pemilih perempuan dalam menggunakan hak pilihnya pada Pemilu tahun 2019 melalui berbagai kegiatan-kegiatan baru, juga menggunakan strategi defensif yang dimaksudkan untuk mempertahankan pemilih perempuan yang selama ini sudah aktif dalam menggunakan hak pilihnya dan terlibat dalam rutinitas kegiatan sosialisasi politik bersama KPU Kota Tangerang Selatan. Strategi defensif yang diterapkan oleh KPU Kota Tangerang 
Selatan dilakukan dengan kegiatankegiatan sebagai berikut: 1) Kerjasama dengan Kader Penggerak PKK Kota Tangerang Selatan Upaya yang dilakukan oleh KPU Kota Tangerang Selatan untuk "merawat" pemilih perempuan yang selama ini sudah aktif dalam menggunakan hak pilihnya dan terlibat dalam kegiatan sosialisasi politik bersama KPU Kota Tangerang Selatan dilakukan dengan cara bekerjasama dengan kader penggerak Pemberdayaan dan Kesejahteraan Keluarga (PKK) Kota Tangerang Selatan sampai ke tingkat Rukun Tetangga (RT). Kerjasama antara KPU Kota Tangerang Selatan dengan penggerak PKK Kota Tangerang Selatan dalam melaksanakan agenda sosialisasi politik dibidang kepemiluan kepada pemilih perempuan sudah dilaksanakan sejak tahapan Pemilu Anggota DPR, DPD, dan DPRD Tahun 2014 Melalui kerjasama tersebut kegiatan sosialisasi kepemiluan dimasukkan sebagai salah satu program kerja PKK Kota Tangerang Selatan bidang Pembinaan Karakter dalam Keluarga (Bidang 1) yang dijalankan sejak tahun 2012. Kerjasama dalam kegiatan sosialisasi kepemiluan anara KPU Kota Tangerang Selatan dengan kader penggerak PKK Kota Tangerang Selatan yang sudah terbangun sejak tahun 2012, semakin diintensifkan pada saat berjalannya tahapan Pemilu tahun 2015, yaitu dengan menambah materi sosialisasi berupa tahapan pemilu. Hal tersebut dimaksudkan untuk mempertahankan dan memperkuat pemahaman tentang materi kepemiluan dan tahapan pemilu bagi seluruh kader penggerak PKK di Kota
Tangerang Selatan. Kader penggerak PKK tingkat RT tersebut merupakan "ujung tombak" dalam melaksanakan kegiatan sosialisasi kepemiluan dan tahapan pemilu tahun 2019 kepada perempuan di lingkungannya yang tergabung dalam kelompok dasawisma. Kemudian anggota dasawisma yang telah mengikuti kegiatan sosialisasi tersebut juga diharapkan dapat menyampaikan informasi kepemiluan dan tahapan pemilu tahun 2019 tersebut kepada seluruh anggota keluarganya. Informasi kepemiluan dan tahapan pemilu tahun 2019 juga disampaikan kepada seluruh anggota keluarga, baik kepada yang sudah ataupun yang belum memiliki hak pilih. Dengan begitu nilai-nilai politik tentang kepemiluan dan tahapan pemilu mulai dikenalkan sejak dini, dimana keluarga merupakan struktur sosialisasi pertama yang dialamai oleh seseorang pada umumnya. Keluarga juga mempunyai pengaruh dalam pembentukan sikap terhadap wewenang kekuasaan, seperti dalam pembuatan keputusan bersama. (Hafidz Liza, 2004). Pengalaman berpartisipasi dalam pembuatan keputusan keluarga dapat meningkatkan perasaan kompetensi politik anggota keluarga, memberikan kecakapan untuk melakukan interaksi politik, dan membuatnya lebih mungkin berpartisipasi secara aktif dalam sistem politiknya. (Masoed dan Mac Andrew, 2011 :47) Kerjasama dengan kader penggerak PKK Kota Tangerang Selatan selain dapat mempertahankan dan memperkuat pemahaman tentang materi kepemiluan dan tahapan pemilu tahun 2019 bagi seluruh kader penggerak PKK 
di Kota Tangerang Selatan, juga bermanfaat bagi perempuan anggota Dasawiswa itu sendiri dalam mendapatkan informasi kepemiluan dan tahapan pemilu tahun 2019. Bahkan lebih jauh dari itu, nilai-nilai politik tentang kepemiluan dan tahapan pemilu tahun 2019 yang disampaikan oleh anggota Dasawisma kepada seluruh anggota keluarganya termasuk kepada anak-anak dapat memberikan manfaat terhadap pengenalan dan pembentukan nilai-nilai politik bagi generasi berikutnya. Pengenalan nilai-nilai politik tentang kepemiluan dan tahapan pemilu tahun 2019 akan tertanam lebih kuat kepada anak-anak apabila melihat praktek secara langsung, bagaimana orangtua atau lingkungan keluarganya yang sudah mempunyai hak pilih dalam berpartisipasi dalam pemilu, seperti mendaftar sebagai pemilih, menonton debat pasangan calon presiden di televisi, dan pada saat datang ke TPS untuk menggunakan hak pilihnya pada hari pemungutan suara. 2) Publikasi Informasi Kepemiluan melalui Website KPU Kota Tangerang Selatan Website KPU Kota Tangerang Selatan merupakan media jaringan berbasis internet sebagai salah satu sarana bagi KPU Kota Tangerang Selatan untuk menyampaikan informasi tentang kepemiluan. Website KPU Kota Tangerang Selatan menjadi rujukan oleh pengguna internet untuk mendapatkan data dan informasi tentang kepemiluan, khususnya tentang pelaksanaan Pemilu secara online. Secara garis besar informasi yang ditampilkan dalam website KPU Kota Tangerang Selatan terbagi menjadi tiga bagian: pertama, berisi informasi tentang kepemiluan yang berisi sejarah KPU Kota Tangerang Selatan, visi, dan misi KPU Kota Magelang, tugas dan kewenangan KPU Kota Magelang, pengertian Pemilu, sejarah Pemilu dan Pilkada, kedua, berisi tentang data berupa hasil penghitungan perolehan suara Pemilu anggota DPR, DPD, dan DPRD tingkat Kota Tangerang Selatan, hasil penghitungan perolehan suara Pemilu Presiden dan Wakil Presiden tingkat Kota Tangerang Selatan, hasil penghitungan suara pemilu, dan produk hukum KPU Kota Tangerang Selatan, ketiga, berisi aktifitas terbaru terkait penyelenggaraan Pemilu KPU Kota Tangerang Selatan telah mempromosikan website sebagai salah satu sarana untuk melakukan sosialisasi kepemiluan kepada masyarakat khususnya pengguna internet, hal tersebut dapat dilihat dari pencantuman alamat website KPU Kota Tangerang Selatan http://www.kpudtangerangselatan.go.id/ ke dalam nomenklatur penulisan tata naskah dinas dan setiap bahan sosialisasi yang dibuat untuk disebarkan kepada masyarakat. Namun pemanfaatan website juga memiliki keterbatasan dalam hal interaksi dengan pengguna, penyampaian informasi hanya berlangsung satu arah. Meskipun KPU Kota Tangerang Selatan telah mencantumkan alamat email resmi sebagai feedback dari pengguna, namun interaksi tersebut berlangsung tertutup antara administrator website dan pengguna saja. Untuk menciptakan keterbukaan, komunikasi yang efektif dan interaktif, serta saling menguntungkan antara KPU Kota Tangerang Selatan 
dengan masyarakat dalam pelaksanaan sosialisasi kepemiluan, seharusnya KPU Kota Tangerang Selatan memanfaat media sosial. Penggunaan media sosial dalam melakukan sosialisasi kepemiluan dapat berpedoman pada Peraturan Menteri Pendayagunaan Aparatur Negara dan Reformasi Birokrasi Republik Indonesia Nomor 83 Tahun 2012 tentang Pedoman Pemanfaatan Media Sosial Instansi Pemerintah. Pemanfaatan media sosial oleh KPU Kota Tangerang Selatan akan mendukung pelaksanaan sosialisasi kepemiluan secara efektif dan efisien, dimana seluruh agenda sosialisasi kepemiluan bisa dengan mudah dan murah untuk disampaikan kepada publik. Berdasarkan pemaparan di atas dapat dilihat bahwa KPU Kota Tangerang Selatan menerapkan dua strategi, yaitu strategi ofensif dan defensif dalam melaksanakan kegiatan sosialisasi politik pada pemilu tahun 2019. Strategi ofensif diterapkan melalui program-program baru yang selama ini belum pernah dilaksanakan pada kegiatan sosialisasi politik bagi pemilih perempuan pada pemilu sebelumnya, dengan tujuan untuk meningkatkan jumlah pemilih perempuan dalam menggunakan hak pilihnya pada pemilu. Sedangkan strategi defensif diterapkan melalui program yang selama ini sudah berjalan dalam melaksanakan kegiatan sosialisasi politik kepada pemilih perempuan, dengan tujuan untuk mempertahankan jumlah pemilih perempuan yang selama ini sudah aktif menggunakan hak pilihnya dan ikut terlibat dalam rutinitas kegiatan sosialisasi politik bersama KPU Kota
Tangerang Selatan kepada pemilih perempuan.

\section{Kesimpulan}

Banyaknya faktor yang menjadi penghambat perempuan di Kota Tangerang Selatan dalam pemilihan umum tahun 2014 menjadi evaluasi bagi penyelenggara pemilihan umum untuk melakukan sosialisasi agar pada pemilihan umum tahun 2019 jumlah partisipasi pemilih perempuan menjadi meningkat. Berbagai upaya dan strategi dilakukan oleh KPU Kota Tangerang Selatan agar perempuan di Kota tangerang Selatan yang sudah memiliki hak pilih dapat menggunakan hak politiknya dengan baik. Untuk itu KPU Kota Tangerang Selatan menerapkan strategi ofensif dan defensif dalam melaksanakan kegiatan sosialisasi politik pada pemilu tahun 2015. Strategi ofensif diterapkan melalui programprogram baru yang selama ini belum pernah dilaksanakan pada kegiatan sosialisasi pada Pilkada sebelumnya. Sedangkan strategi defensif diterapkan melalui program yang selama ini sudah berjalan dalam melaksanakan kegiatan sosialisasi politik kepada pemilih perempuan. Penerapan strategi ofensif lebih mendominasi dalam peningkatan partisipasi pemilih perempuan pada pemilu tahun 2019. Hal ini dapat dilihat dari beragamnya program baru yang dijalankan dan direspon positif oleh pemilih perempuan. Disamping itu, KPU Kota Tangerang Selatan juga tidak mengabaikan strategi defensif, hal ini ditunjukkan dengan tetap terpeliharanya kerjasama dengan kader penggerak PKK 
Jurnal Pendidikan Kewarganegaraan

Vol. 6 No. 1 Maret 2019

Kota Tangerang Selatan yang selama ini sudah terbangun dan ikut terlibat dalam rutinitas kegiatan sosialisasi politik bersama KPU Kota Tangerang Selatan kepada pemilih perempuan. Untuk itu keterlibatan berbagai pihak dalam mensosialisasikan pentingnya perempuan dalam partisipasi politik ini sangat dibutuhkan, tidak hanya KPU saja, namun juga peran ini harus dilakukan oleh berbagai lapisan masyarakat mulai dari tingkat RT, RW maupun organisasi kelembagaan lainnya yang ada di masyarakat.

\section{Referensi}

Bagian Bina Partisipasi Masyarakat Biro Teknis dan Hupmas KPU. (2015). http://www.kpudtangerangselatan.go.id/

Hadiz, L, dkk. (2004). Perempuan Dalam Wacana Politik Orde Baru. Jakarta: Pusaka LP3ES.

Hamka. B. (2017). Berbicara Tentang Perempuan. Jakarta: Gema Insani.

Hatima, T. dkk. (2000). Analisis Gender. Workshop 13-19 November 2000. Jakarta: IAIN Syahid .

KPU. (2016). Partisipasi Pemilih Pilkada Serentak Tahun 2015. Jakarta: Komisi Pemilihan Umum.

Mar'iyah, C. (2001). Transisi Demokrasi dan Konsolidasi: Peran Negara dan Peluang Gerakan Perempuan. Jurnal Analisis Sosial.

Mas`oed, M., \& MacAndrews, C. (2011). Perbandingan Sistem Politik. Yogyakarta: Gadjah Mada University Press

Nur H. S. (2011). Restorasi Penyelenggaraan Pemilu di Indonesia, Yogyakarta: Fajar Media Press,
Pusat Kajian Wanita dan Gender. (2007). Hak Azasi Perempuan Instrumen Hukum Untuk Mewujudkan Keadilan Gender. Jakarta: Yayasan Obot Indonesia..

Rush, M., \& Althoff, P. (2013). Pengantar Sosiologi Politik. (K. Kartono, Trans.) Jakarta: Rajawali Pers.

Sarwono, J. (2006). Metode Penelitian Kantitatif \& Kualitatif. Yogyakarta: Graha Ilmu.

Scroder, P. (2010). Strategi Politik (Edisi Cetakan Ketiga ed.). (A. Agoesman, Trans.) Jakarta: Friedrich-NaumannStiftung fuer die Freiheit. 
Jurnal Pendidikan Kewarganegaraan

Vol. 6 No. 1 Maret 2019
Journal of Civics and Education Studies p-ISSN 2302-0865 | e-ISSN 2621-346X

[ halaman ini sengaja dikosongkan ] 